\title{
Factors Influencing Students` Pronunciation Mastery at English Department of STKIP PGRI West Sumatera
}

\author{
Received:09 ${ }^{\text {th }}$ Mei 2017; Revised: $18^{\text {th }}$ Mei 2017; Accepted: $25^{\text {th }}$ July 2017 \\ Permalink/DOI: http://dx.doi.org/10.15548/jt.v24i2.279
}

\section{Muhammad Khairi Ikhsan}

Sekolah Tinggi Keguruan dan Ilmu Pendidikan PGRI Sumatera Barat, Padang, Indonesia.

E-mail: khairi84ikhsan@gmail.com

\begin{abstract}
The research is to find the dominant factors influencing students` pronunciation mastery at English department of STKIP PGRI West Sumatera. This research is using qualitative research method. Total of participants are 10 English students academic year 2016/2017 in English Department of STKIP PGRI West Sumatera who are getting the best mark in pronunciation class. Sample of the research was selected by using purposive sampling technique. The instrument of the research is interview. The purpose of the interview is to get the real arguments about factor influencing students pronunciation mastery. This research revealed that motivation is the dominant factor influencing students` pronunciation mastery. Most of the students were motivated to increase their pronunciation because they were motivated by native speakers-watching the western or English movies and songs. Besides, they also argued that they wanted to go to overseas so, they should produce the word with correctly pronounced to avoid misunderstanding for both speaker. Based on the data obtained, it can be stated that motivation is the dominant factor influencing students` pronunciation mastery in academic year 2016/2017 at English Department of STKIP PGRI West Sumatera.
\end{abstract}

Keywords: Influenced factors, pronunciation, pronunciation mastery

How to Cite: Ikhsan, M. (2017). Factors influencing students` pronunciation mastery at English department of STKIP PGRI West Sumatera. Al-Ta Lim Journal, 24 (2). doi:http://dx.doi.org/10.15548/jt.v24i2.279

\section{INTRODUCTION}

Pronunciation has always been perceived as a difficult area by teachers and learners alike. Like listening, pronunciation is sometimes neglected in the process of language teaching in favor of reading and writing, which are rather more likely to lead to success in examination of cultures which are so much more focused on those media. However, it seems rather pointless to study a (living) foreign language at all if one does not intend to communicate in it with other speakers of that language and, to this end; one must learn how to pronounce it in a way which can be understood by a variety of listeners. English, whether by accident of story, foreign policy, or through purposeful educational policy, has arisen as a world lingua franca, and being intelligible when speaking it has therefore received a great deal of attention. 
Pronunciation refers to the production of sounds that we use to make meaning. To speak something a person has word stress, sentence stress, and intonation. That's all are part of pronunciation. Pronunciation is very important in communication. Communication needs understanding between speaker and listener. When someone's pronunciation is wrong, it makes misunderstanding between the speaker and listener although vocabulary and grammar are good but if the pronunciation is not clear, the communication is not run well.

In everyday communication, the people do not have to use many complicated words, so limited vocabulary is not a big problem since the people can use more simple words. If the people have poor pronunciation, other people will call them as bad English speaker and good vocabulary and grammar cannot help the people when doing communication (Breitkreutz, Derwing, \& Rossiter, 2001; Derwing \& Munro, 2005; Jenkins, 2004; Levis, 2005). When we talk to other people in English, the first thing they notice, which can create good impression about the quality of our language ability, is our pronunciation. Poor and unintelligible pronunciation will make unpleasant and misunderstanding for both speakers and listeners. In addition, it is clear that limited pronunciations skills will make learners lose their self-confidence and result in negative influence for learners to estimate their credibility and abilities.

Furthermore, teaching pronunciation in a good way is very essential to be considered by lecturer. Lecturer need to prepare everything before teaching, so the students can catch the point from the teaching learning process. Based on the syllabus for teaching learning process in STKIP PGRI West Sumatera, teaching pronunciation will teachable in first semester. All of the variable of the pronunciation have to be taught by lecturer well in preparing the students before they continue their study to the next level of pronunciation.
Pronunciation is difficult thing to some students that English is a foreign language of them. Pronunciation mastery for some people is influenced by some factor they are some factors that affecting native-like pronunciation. These variables include native language, age, exposure, innate phonetic ability, identity and language ego, motivation, and concern for good pronunciation. Incontestably, it is not easy to give an intact list for affecting factors in pronunciation (Desfitranita, 2017; Munandar, 2015; Sukandi \& Sani, 2017).

Based on the researcher's preobservation at students of English Department in STKIP PGRI West Sumatera, that are found some students that have good in pronunciation although some of them seldom used or practice to speak English in their life, because they interact in area English is a foreign language. Sometimes some of them do not enthusiastic when following teaching learning process especially to know clearly about pronunciation, but they were able to pronounce the word.

Furthermore, in order to complete this research, the researcher uses several theories that give a beneficial support toward this research. The first one is Gamboa Silva (2011) several factor that influencing pronunciation mastery as follow:

a. Age.

Pronunciation is more difficult than children do and that they probably will not achieve native-like pronunciation.

b. Aptitude.

Learners have the same capacity to learn a second language because they have learned a first language. Others assert that the abilility to recognize and internalize foreign sounds may be unequally developed in different learners.

c. Learner attitude and motivation.

Attitude toward the target language, culture, and native speakers; degree of acculturation; personal identity issues; and motivation for learning can all 
support or impede pronunciation skills development.

Celce-Murcia \& UCLA (2013) argues several factors that influence students 'pronunciation mastery as follow:

a. Age of the learner

Young children can acquire good pronunciation more easily than adults; also the Children and adults learn pronunciation in different ways. Adults also have some advantages in learning pronunciation.

b. Exposure to the target language

Greater exposure to the target language makes it easier to acquire good pronunciation.

c. Amount and type of prior pronunciation instruction

If learners have had good pronunciation training before, this will help them. If they've had ineffective training or no training, they're at a disadvantage.

d. Aptitude, attitude, and motivation

Some people may have a "talent" for pronunciation and People who are more adaptable may have more success in pronunciation.

e. The role of the native language

The learner's native language affects the learning of pronunciation sometimes this effect is bad, but sometimes it is good. An L1 sound may be substituted for an L2 sound. The phonological rules of L1 may be mistakenly applied to L2.

f. New directions in research

In teaching pronunciation, we shouldn't think only about individual sounds. Intonation, rhythm, and changes in connected speech are also important.

According to Gatbonton, Trofimovich, \& Magid (2005), some factor influencing students pronunciation mastery in pronunciation there are age, amount and type prior pronunciation instruction, aptitude, learner attitude and motivation, native language.
Moreover, Gilakjani \& Ahmadi (2011) explains that some factor influencing student's pronunciation mastery. They are motivation and exposure; exposure to target language; attitude and instruction. Then age and the last mother tongue.

In short, there are four experts explain about factor that influenced students 'pronunciation mastery such as accent, motivation and exposure, attitudes, instruction, age, personality etc. In this research the researcher will combine and choose the opinion from the experts that related with factor of the students' pronunciation mastery.

\section{METHOD}

In this research the researcher used descriptive qualitative research because the researcher wanted to find the data about the factor of the students pronunciation mastery. According to Gay, Mills, \& Airasian (2011) descriptive research study determines and describes the way things are. It means that, descriptive research focused on describing phenomenon. The researcher chooses descriptive research because the researcher wanted to find the data about the factor of the students pronunciation mastery. In this research, for answering the research question, the researcher described and analyzed the factor of students' pronunciation mastery at English department of STKIP PGRI West Sumatera. The participants of this research was 10 English student academic year 2015/2016 in English Department of STKIP PGRI West Sumatera where are getting a high value in pronunciation class as the participants. In this research, the researcher used purposive sampling to get the data from the students. According to Ary, Jacobs, \& Razavieh (2010), purposive sampling also referred to as judgment sampling, sample elements judge to be typical, or representative, are chosen from the population. The using of purposive sampling means that researcher got the samples based on researcher`s needs.

The researcher used interview to collecting the data and to analyze about the 
dominant factor influencing students pronunciation mastery at English Department of STKIP PGRI West Sumatera academic year 2016/2017 During interview the researcher used the camera or hand phone took some pictures and record in interview process.

On the other side, to make this research run optimally, the researcher used interview as technique of data collection. Interview is used for help the researcher to finds some the data along research process. According to Gay \& Airasian (2000) qualitative interview occurs when researcher asked one or more participants general, open-ended questions and record their answers. It means that interview is communication between researcher and participant directly to get some information. Researchers do interview to English student academic year 2016/2017 years at STKIP PGRI West Sumatera. In this research interview had function for making information from observation more strength. In this research, the researcher used semi structured interview to getting accurate data about the factor influencing students' pronunciation mastery at English department of STKIP PGRI West Sumatera.

At the end, the researcher analyzed the data that are gotten from those two techniques. According to Gay \& Airasian (2000), there are four steps of analyzing the data; reading/memoing, describing, classifying, and interpreting:

a. Reading/memoing, becoming familiar with the data and identifying the main themes. In this stage, the researcher would read the data from interview. It was done to make the researcher familiar enough with the data gotten.

b. Describing, examining the data in depth to provide detail description of setting, participants, and activities. In this stage, the researcher described the factor of students` pronunciation mastery the result of interview c. Classifying, categorizing and coding pieces of data and physically grouping them into themes In this stage, the researcher would classify the data by seeing the result of interview.

d. Interpreting and synthesizing the organize data into general understanding. After the researcher got the data, the researcher would interpret the data clearly

\section{RESULTS AND DISCUSSIONS}

Dealing with the data analysis which had been done through four stages: reading / memoing (reviewing and relicensing audio tapes, rereading transcripts), Describing (examining the data in depth to provide detail description of setting, participants, and activities), Classifying, categorizing and coding pieces of data, and Interpreting and synthesizing the organize data into general understanding. The researcher formulates the finding and discussion of this research as follow:

In this chapter, the researcher explained about data description, data analysis, findings and interpretation. After conducting a research about factor influencing students pronunciation mastery at English department of STKIP PGRI West Sumatera, researcher got the data and findings.

Some of the student feels instruction from the lecturer makes them understand to pronounce the word in English. Also some of the student that mastery in pronunciation is from the increase their pronunciation by the song and often practice to spoke in English to train the ability in pronunciation, most of the students did not use English when they were child, some of the students could adapt their pronunciation without affected by the accent or mother tongue, and only several student that found difficulties in some alphabet because in their region, this alphabet is very specific.

Some of the student feel that they were mastery in pronunciation, before that got the instruction about pronunciation, they were mastery because of they often increase their 
skill in daily life and the students that mastery in pronunciation don't always have good attitude.

Almost of the students never had a religion with native or the people around them that used English as a first language.
Most of the students were motivated by the native speaker and also some of them like to watch the west movie and west song. For further details about the factors influencing students' pronunciation mastery can be seen in the following table:

Table 1. Research Finding Based on Observation and Interview about Factors Influencing Students' Pronunciation Mastery

\begin{tabular}{|c|c|c|}
\hline No & Indicators & Note \\
\hline 1 & Education & $\begin{array}{l}\text { Some of the student feels instruction from the lecturer makes them } \\
\text { understand to pronounce the word in English. Also some of the student that } \\
\text { mastery in pronunciation is from the increase their pronunciation by the } \\
\text { song and often practice to speak in English to train the ability in } \\
\text { pronunciation. }\end{array}$ \\
\hline 2 & Age & $\begin{array}{l}\text { Most of the students did not use English when they were a child. The student } \\
\text { seldom practice to speaks English, because the student just speak English only } \\
\text { when they in English class, and when the teacher ask them to practice in the } \\
\text { class. }\end{array}$ \\
\hline 3 & $\begin{array}{c}\text { Accent/ } \\
\text { Mother Tongue }\end{array}$ & $\begin{array}{l}\text { Accent/ mother tongue in the students region is really different from English } \\
\text { language although is intonation, stressing and so on but it's not be obstacle } \\
\text { when the students pronounce the word in English. According to the students, } \\
\text { the difference of the accent it can be overcome. Most of the students can adapt } \\
\text { their pronunciation without affect by the accent or mother tongue, and only } \\
\text { several students that found difficulties in some alphabet because in their } \\
\text { region, this alphabet is very specific. }\end{array}$ \\
\hline 4 & Aptitude & $\begin{array}{l}\text { Some of the student feel that they are mastery in pronunciation is before they } \\
\text { get the instruction about pronunciation; they are mastery because they are } \\
\text { often increasing their skill in daily life. }\end{array}$ \\
\hline 5 & Attitude & $\begin{array}{l}\text { In this indicator, the researcher found the argument from several students that } \\
\text { they want to study pronunciation because they feel bored, and several of the } \\
\text { students said that they want to study about pronunciation because they are feel } \\
\text { so happy when study English. It means that the students who are mastery in } \\
\text { pronunciation don't always have good attitude because normally the students } \\
\text { who are have good attitude they certain to learn about pronunciation more, } \\
\text { and never say bored to learn. And based on the researcher experience some } \\
\text { students that have good attitude in the pronunciation class did not have } \\
\text { mastery in pronunciation, although they came on time, always doing the task } \\
\text { or complete their task and did not make a noisy in the class, but they did not } \\
\text { mastery in pronunciation. They were still difficult when they speaks in } \\
\text { English and pronounce the word }\end{array}$ \\
\hline 6 & Exposure & $\begin{array}{l}\text { The researcher found almost of the students never has a religion with native or } \\
\text { the people around them, who are use English as a first language. When the } \\
\text { researcher ask about exposures almost of the students answer "no". }\end{array}$ \\
\hline 7 & Motivation & $\begin{array}{l}\text { Most of the students have the different reason why they are interest to develop } \\
\text { their pronunciation. The researcher found most of the students want to achieve } \\
\text { their dreams so they should mastery in pronunciation. Because if they are did } \\
\text { not mastery in pronunciation they would get difficulty to get the dreams. Most } \\
\text { of the students are motivated by the native speaker and also some of them like } \\
\text { to watch the west movie and west song. It made them want to mastery in } \\
\text { pronunciation because when they want to sing a song they wanted to produce } \\
\text { the words with correctly pronounce. The students said that they often to } \\
\text { practice in their daily life, so it make them to mastery in pronunciation }\end{array}$ \\
\hline
\end{tabular}

Based on the result of interview sheet have been distributed by students at STKIP PGRI West Sumatera academic year
2015/2016. The researcher got information from the students about influencing pronunciation mastery. At the interview, the 
students said that motivation is the important thing to make them mastery in pronunciation. They argument state that the motivation be the dominant factor influencing pronunciation mastery because from 10 of the students, 8 of them motivated to increase their pronounce skill. Be sides 6 of the students influencing their pronunciation from the education or instruction but if they do not have motivation to increase and practice about their pronunciation, the students don't be mastery in pronunciation.

\section{Interpretation}

Based on result the data analysis above, the researcher interpreted about the dominant factor influenced pronunciation mastery. During the research, the researcher found the argument of the factor students' pronunciation mastery

The researcher assumed that motivation becomes the dominant factor that influence student's pronunciation mastery. The researcher described based on sequence of indicators characteristic of students' pronunciation mastery. It consists of education, age, accent/mother tongue, aptitude, attitude, exposure, motivation.

\section{Education}

Based on to Derwing \& Munro (2005) state that," prior experiences with pronunciation instruction may influence learners` success with current efforts." It means that education or instruction give influencing students` pronunciation mastery. But in the data analysis the researcher found education was not be the dominant factor influencing students` pronunciation mastery because from 10 student, only 6 of the students answered education in the campus influence them in pronunciation mastery.

\section{Age}

Based on theory Gamboa Silva (2011) said that," Pronunciation more difficult than children do and that they probably will not achieve like native pronunciation". It means that, the students that increased their pronunciation when child, they would mastery in pronunciation but in this research, the researcher found age was not be the dominant factor influencing students pronunciation mastery because the students` mastery in pronunciation did not increased their pronunciation since their child. 2 of the students also practiced their pronunciation skill from their child or started from their in the school.

\section{Exposure}

According to Celce-Murcia \& UCLA (2013) great exposure to the target language makes it easier to acquire good pronunciation". It means that exposure give influence to students' pronunciation mastery, but the data was analyze exposure was not be the dominant factor influencing students pronunciation mastery because, 3 of 10 of the students had friend that used English in their daily life to make them mastery and learn about how to pronounce the word. So it can be the reason why exposure was not be the dominant factor influencing students` pronunciation.

\section{Motivation}

Based on the theory of Gamboa Silva (2011) state that "motivation for learning can all support or impede pronunciation skill development." This theory balance with the data was analyzed to the researcher. Because the researcher found 8 of the students had big motivation and differences motivation that make them mastery in pronunciation. The students always practice and always do the work that make their pronunciation mastery So we can conclude that motivation is the dominant factor influencing students pronunciation mastery because motivation had high scoring from 7 indicator.

\section{Accent/ Mother Tongue}

Accent/Mother tongue of the students is really differences with English language. 
Although is stressing, intonation, pressing and so on. But the data was analyzed, its not be the problem to the students to mastery in pronunciation. The accent/Mother Tongue was not be the dominant factor influencing students` pronunciation mastery, because the students felt they can adapted the tongue when they spoke in English. Only 3 of 10 students felt not comfortable in some alphabet because in their region, there are some alphabet that specific to produce when their spoken.

\section{Aptitude}

Based on the theory of Gamboa Silva (2011) said that," learners have same capacity to learn a second language." It means that the students who were mastery in pronunciation had same capacity to learn a second language so the student that had good aptitude would be mastery in pronunciation, but the data was analyzed and found that aptitude was not be the dominant factor influencing students pronunciation mastery because only 4 of 10 students that had aptitude. 6 of them was influenced by another factor.

\section{Attitude}

According to Gamboa Silva (2011) state that." Attitude toward the target language, culture and native speaker, degree of acculturation, personal identity issues, can all suport or impede pronunciation skills development. The data was analyzed that attitude was not be the dominant factor influencing students` pronunciation mastery, because 4 of 10 the students that were mastery in pronunciation had good attitude, some of the students that mastery in pronunciation, seldom had good attitude, and the student that had good attitude in pronunciation class don't have mastery in pronunciation.

\section{CONCLUSION AND RECOMMENDATION}

The purpose of this research is to know what are the factors that influence students' pronunciation?. The dominant factor influenced students` pronunciation mastery at English department of STKIP PGRI West Sumatera. Based on the research findings, the researcher formulates the conclusion into the result of Department of STKIP PGRI West Sumatera academic year 2015/2016. From 7 indicators, the most influencing students pronunciation mastery is motivation because, it show by the student's argument about motivation. 8 of 10 students reveal that they motivate of the motivation with some reason.

The data show the motivation is very influence to have mastery in pronunciation. The students that have motivation such as want to go to the foreign, wants to like native when speak or pronounce the word, wants to continue their school to the foreign and want to be good English teacher for their students later. Statements from the students make they want to increase their pronunciation, they always practice always correct their pronunciation in their daily life. it means that motivation can be the dominant factor in influencing students` pronunciation mastery.

\section{REFERENCES}

Ary, D., Jacobs, L. C., \& Razavieh, A. (2010). Introduction to research in education 8th edition, Wardswoth Cengage Learning. Canada: Nelson Education Ltd Exotic Classic.

Breitkreutz, J., Derwing, T. M., \& Rossiter, M. J. (2001). Pronunciation teaching practices in Canada. TESL Canada Journal, 19(1), 51-61.

Celce-Murcia, M., \& UCLA, E. (2013). Language teaching methods from the Greeks to Gattegno1 2.

Derwing, T. M., \& Munro, M. J. (2005). Second language accent and pronunciation teaching: A research- 
based approach. Tesol Quarterly, 39(3), 379-397.

Desfitranita, D. (2017). Students' rules and practices: how to speak English fluently? Al-Ta Lim Journal, 24(1), 1928.

Gamboa Silva, L. P. (2011). Strategies to improve english pronunciation in young learners (B.S. thesis). Pontificia Universidad Católica del Ecuador Sede Ambato.

Gatbonton, E., Trofimovich, P., \& Magid, M. (2005). Learners' ethnic group affiliation and L2 pronunciation accuracy: A sociolinguistic investigation. TESOL Quarterly, 39(3), 489-511.

Gay, L. R., \& Airasian, P. (2000). Educational research: Competencies for. Analysis and Application,(6th Edition). Ohio: Prentice Hall.

Gay, L. R., Mills, G. E., \& Airasian, P. W. (2011). Educational research: Competencies for analysis and applications. Pearson Higher Ed.
Gilakjani, A. P., \& Ahmadi, M. R. (2011). A Study of factors affecting EFL learners' English listening comprehension and the strategies for improvement. Journal of Language Teaching \& Research, 2(5).

Jenkins, J. (2004). 5 Research in teaching pronunciation and intonation. Annual Review of Applied Linguistics, 24, 109 125.

Levis, J. M. (2005). Changing contexts and shifting paradigms in pronunciation teaching. Tesol Quarterly, 39(3), 369377.

Munandar, I. (2015). How does English language learning contribute to social mobility of language learners? Al-Ta Lim Journal, 22(3), 236-242.

Sukandi, S. S., \& Sani, R. D. (2017). EFL students' responses on learning academic essays in Indonesian Higher Education. Al-Ta Lim Journal, 24(1), $37-46$. 